\title{
Erratum to: How Historical ThinkingHelps with Technology Decision-Making
}

\author{
Bernard Bull ${ }^{1}$
}

Published online: 24 June 2016

(C) Association for Educational Communications \& Technology 2016

Erratum to: TechTrends (2016) 60:313-315

DOI 10.1007/s11528-016-0068-x

In the article, How Historical Thinking Helps with Technology Decision-Making, the reference attributed to Neil Postman is more accurately assigned the following source: Hartmann, T. (2012, September 25). A short history of grading. Retreived from http://www.joebower.org/2012/09/a-short-history-ofgrading.html. While the section cited in Postman's work does indeed address William Farish, this other citation aligns more directly with the claims about William Farish in the article. However, as stated in the original article, these claims about William Farish remain unverified beyond this updated source from Thom Hartmann.

The online version of the original article can be found under doi:10.1007 /s11528-016-0068-x.

\author{
Bernard Bull \\ bernard.bull@gmail.com \\ 1 Concordia University, Mequon, WI, USA
}

